logos_i_ethos_2016_(40)_numer_specjalny_1, s. 13-28

DOI: http://dx.doi.org/10.15633/lie.1695

Magdalena Żardecka-Nowak

Uniwersytet Rzeszowski

\title{
Księgozbiory radości, czyli o sztuce pisania, czytania i kompletowania bibliotek
}

\author{
„książka tworzy sens, sens tworzy życie” \\ R. Barthes ${ }^{1}$ \\ „szczęście jest poniekąd tym, co zatrzymuje \\ prący do przodu pęd pragnienia"
}

P. Ricoeur ${ }^{2}$

Szczęście, przyjemność, radość i zadowolenie na ogół były traktowane przez filozofów $\mathrm{z}$ rezerwą i podejrzliwie. Już w starożytności dostrzeżono problem $\mathrm{z}$ definicją przyjemności, mnogością jej rodzajów oraz z ich hierarchią (przyjemności wyższe i niższe, godziwe i niegodziwe, proste i złożone; hedonizm

Magdalena Żardecka-Nowak, dr hab., prof. Uniwersytetu Rzeszowskiego, Zakład Antropologii Kulturowej UR. Zainteresowania naukowe: filozofia społeczna, filozofia polityczna, filozofia współczesna. Ważniejsze publikacje: Wspólnota i ironia. Richard Rorty i jego wizja społeczeństwa liberalnego, Lublin 2003; Rozum i obywatel. Idea rozumu publicznego oraz koncepcja jednostki we współczesnej filozofii polityki, Rzeszów 2007. konsekwentny i niekonsekwentny), dostrzeżono też, że cel i sens ludzkiego życia (telos) nie daje się w wyczerpujący sposób zdefiniować w terminach tego, co subiektywnie przyjemne. Myśliciele starożytni dostrzegali, że życie dobre - pojmowane jako obiektywny stan pomyślności i doskonałości charakteru (eudaimonia) ${ }^{3}$ -

1 R. Barthes, Przyjemność tekstu, tłum. A. Lewańska, Warszawa 1997, s. 43.

2 P. Ricoeur, O sobie samym jako innym, tłum. M. Kowalska, Warszawa 2003, s. 288.

3 Por. Eudaimonia, [w:] Encyklopedia filozofii, red. T. Honderich, tłum. J. Łoziński, Poznań 1998, s. 226-227. 
nie jest tym samym, co życie przyjemne, a życie przyjemne nie musi być życiem dobrym (niemniej jednak nie formułowali takich radykalnych koncepcji etycznych jak Immanuel Kant, zdaniem którego nakazy moralności są zupełnie oderwane od ludzkiej pomyślności). Sokrates oraz stoicy wielką wagę przywiązywali do cnoty (stałość charakteru w tym, co dobre), Arystoteles dodawał do niej szereg zewnętrznych i obiektywnych czynników życiowego powodzenia (zdrowie, dostatek), epikureizm zachęcał do praktykowania skromności i ascezy, a unikanie cierpienia uznawał za jedyną osiągalną przyjemność. Pojęcie szczęścia odegrało nadrzędną rolę $\mathrm{w}$ dziewiętnastowiecznym utylitaryzmie, który upatrywał w nim ostatecznego celu wszystkich ludzkich poczynań (Jeremy Bentham, John Stuart Mill) ${ }^{4}$.

Już w starożytności zauważono, że niektóre przyjemności nie są czystą pozytywnością. Ludzkie zadowolenie posiada swą ciemną stronę (zwracał na to uwagę np. Sokrates): wynosić się nad innych, uważać się za kogoś lepszego, móc krzywdzić innych, nie będąc narażonym na zemstę ani karę, poniżać, upokarzać, wykorzystywać, zniewalać, cieszyć się z cudzego nieszczęścia, cudze nieszczęście powodować, triumfować nad kimś - to haniebny, sadystyczny cień przyjemności, dowodzący istnienia demonicznego aspektu ludzkiej natury. Filozofia na ogół starała się go przemilczeć, jedynie nieliczni autorzy, tacy jak Thomas Hobbes, Arthur Schopenhauer, Zygmunt Freud i Jean-Paul Sartre, próbowali się z nim intelektualnie zmierzyć.

\section{Przyjemność w ujęciu Freuda}

Zygmunt Freud przedstawiał życie psychiczne człowieka jako teren zmagań dwóch zasad - zasady przyjemności i zasady rzeczywistości. Uważał, że wrodzona jest nam zasada przyjemności, która nakazuje unikać cierpień i przykrości, redukować napięcia i podążać za tym, co przyjemne.

4 Bentham utożsamiał szczęście i przyjemność i przykładał do nich miary wyłącznie ilościowe. Mill zaś za szczęściorodne uważał tylko przyjemności wyższe: wyobraźni, intelektu i moralnych uczuć. 
Zasada ta powoduje automatyczną regulację napięcia w organizmie, przy czym nakierowuje się na przyjemność aktualną, a nie na możliwość uzyskania przyjemności w długofalowej perspektywie. W przypadku braku natychmiastowej satysfakcji jednostka (dziecko) ucieka w świat halucynacji, marzeń, snów, iluzji, imaginacji, w którym osiąga upragniony cel. Zasada przyjemności wiąże się z przymusem powtarzania ${ }^{5}$. Przymus ten jest udręką i rozkoszą duszy pokutującej, która nie może zaznać spokoju. Zdaniem Freuda minione doświadczenia, które nie były przez nas właściwie zrozumiane, lecz zostały przez naszą psychikę wyparte i zakłamane, nękają nas i nawiedzają pod różnymi postaciami (przejęzyczenia, chwilowa utrata pamięci, objawy somatyczne, takie jak drżenie rąk, bóle głowy, omdlenia, nerwica przeznaczenia, nerwica pourazowa, natręctwa, obsesje) ${ }^{6}$. Uporczywe, przymusowe realizowanie wypartego (nieświadomego) pragnienia stanowi swoiste połączenie przyjemności i przykrości. Pod widocznym na powierzchni cierpieniem spełnia się pragnienie, dając namiastkę przyjemności i satysfakcji; pod pozorem przyjemności skrywa się nieopisana udręka. Niełatwo uwolnić się od przymusu powtarzania. Potrzebne jest $\mathrm{w}$ tym celu przepracowanie swojej przeszłości ${ }^{7}$. Można powiedzieć, że Freud odkrył złożoność, wielowarstwowość ludzkiej psychiki; pokazał, że to, co jest nieprzyjemne dla jednego systemu (aparatu psychicznego), może być przyjemne dla innego i odwrotnie.

Potrzeba powtarzania okazuje się sama w sobie potrzebą domagająca się zaspokojenia. Wyjaśniałoby to zjawisko powracania podmiotu do sytuacji bolesnych, trudnych, napawających grozą i przerażeniem (trauma). Zarówno zasada przyjemności, jak i zasada powtarzania pozostają zdaniem Freuda w służbie popędu śmierci. Powtarzanie odracza napięcie, choć go nie rozładowuje, odracza też śmierć, choć ją przywołuje na wiele sposobów.

5 Por. Z. Freud, Poza zasada przyjemności, tłum. J. Prokopiuk, Warszawa 2005; por. też Z. Freud, Popędy i ich losy, tłum. K. Rak, [w:] Z. Rosińska, Freud, Warszawa 1993, s. 136-148.

6 Dziełem Freuda, które w całości poświęcone jest zapomnieniom, przejęzyczeniom, pomyłkom i błędom, jest Psychopatologia życia codziennego. Marzenia senne, tłum. L. Jekels, H. Ivanka, W. Szewczuk, Warszawa 1987.

Por. Z. Freud, Przypominanie, powtarzanie, przepracowanie, tłum. A. Czownicka, [w:] K. Pospiszyl, Zygmunt Freud. Człowiek i dzieło, Wrocław-Warszawa-Kraków 1991, s. 266-272. 
Jednostka kierująca się w życiu zasadą przyjemności faktycznie ucieka przed wolnością i przed samym życiem (poszukiwanie bezpieczeństwa).

Przeciwieństwem zasady przyjemności jest zasada rzeczywistości. Dziecko uczy się tego, że nie można natychmiast zaspokajać potrzeb, oraz tego, że wyobraźnia, halucynacje, marzenia nie prowadzą do osiągnięcia celu. Rzeczywistość domaga się odraczania, wyczekiwania, obchodzenia pożądanego celu. Z ekonomicznego punktu widzenia zasada rzeczywistości polega na przekształcaniu energii swobodnej, obecnej w ślepym popędzie, w energię związaną, skutecznie prowadzącą do faktycznego zaspokojenia potrzeby. Zasada ta pozostaje w służbie Ego (dynamiczny punkt widzenia, popęd samozachowawczy), podczas gdy zasada przyjemności służyła Id (popęd seksualny i śmierć). Zasada rzeczywistości pojawia się po zasadzie przyjemności, jako późniejszy etap rozwoju psychicznego. Wiążą się z nią takie umiejętności jak: uwaga, pamięć, zdolność oceny sytuacji, zdolność działania i przekształcania rzeczywistości, zdolność podejmowania decyzji i ponawiania prób, zdolność stawiania hipotez, zdolność znoszenia porażek, zdolność wyciągania wniosków i uczenia się na błędach. Przejście do zasady rzeczywistości nie oznacza zniesienia zasady przyjemności. Podporządkowanie się zasadzie rzeczywistości pozwala na realizacje potrzeb $\mathrm{w}$ realnym świecie, a nie w świecie wyimaginowanym. Zasada przyjemności króluje jednak nadal w nieświadomości dorosłego.

Konflikt między Ja i To jest stałym elementem naszego życia psychicznego. W procesie rozwoju Ja oddziela się od To w wyniku kontaktu z rzeczywistością. Ja kieruje się zasadą rzeczywistości i dąży do zaspokojenia swych potrzeb dzięki poznaniu otoczenia, orientacji w tym, co teraźniejsze, umiejętności korzystania z minionych doświadczeń, zdolności myślenia i przewidywania. Ja może uznać, że zaspokojenie pewnych potrzeb należy odłożyć na później, a także że niektóre żądania popędu trzeba po prostu stłumić. Popędy początkowo funkcjonujące zgodnie z zasadą przyjemności stopniowo podporządkowywane są zasadzie rzeczywistości. Ja związane z przyjemnością nie zna nic poza pragnieniem i chęcią uniknięcia przykrości, Ja związane z rzeczywistością stara się o to, co jest potrzebne do życia, unika zaś tego, co jest szkodliwe. Są to zatem dwie różne formy Ja. Ja związane z przyjemnością ucieka od rzeczywistości 
jako źródła przykrości - infantylny podmiot dba o to tylko, by życie było pasmem przyjemności; chce się sobie kojarzyć wyłącznie z tym, co przyjemne (introjekcja), a świat i innych obarczyć winą za to, co przykre (projekcja). Infantylne Ja oczyszcza się samo przed sobą z wszelkich zarzutów i przewinień, z wszystkiego, co przykre i złe ${ }^{8}$.

Zdaniem Freuda probierzem ludzkiej dojrzałości jest zdolność stawiania czoła rzeczywistości. Łowcy przyjemności to infantylni, tchórzliwi uciekinierzy od świata i prawdy, którzy pragną jedynie bezpieczeństwa, pochlebstw i opowieści konsolacyjnych. Skazani są jednak na porażkę i rozczarowanie, nawet gorzej - oni sami są porażką i rozczarowaniem dla świata, w którym sieją wyłącznie pustkę.

\section{Paradoks czytania}

Pisanie, czytanie oraz gromadzenie książek jest rodzajem przyjemności, jakiej oddają się niektórzy spośród nas. W świetle teorii Freuda pasja ta jest tylko jednym z rodzajów ucieczki od świata, infantylnym sposobem zaspokajania potrzeby bezpieczeństwa (bujanie w obłokach, chodzenie $\mathrm{z}$ głową $\mathrm{w}$ chmurach, karmienie się fantazmatami), tchórzliwym rozmijaniem się z rzeczywistością (przebywaniem w krainie wyobraźni).

Jednak teoria ta nie jest jedyną mogącą wyjaśnić, skąd bierze się nasze zamiłowanie do pisania i do lektury. Co najmniej równie poważna jest teoria hermeneutyczna traktująca czytanie i interpretowanie tekstów jako okrężną (nieprowadzącą na skróty), wymagającą czasu i zaangażowania drogę do rozumienia, poznania, prawdy i wiedzy. W ujęciu hermeneutycznym czytanie i pisanie (nawet w przypadku literackiej fikcji) to poznawanie, żmudne docieranie do prawdy, która nie jest nam dana wprost w bezpośrednim doświadczeniu (np. prawda o przeszłości, o życiu wewnętrznym innych, o życiu jako pewnej całości od narodzin do

8 Por. Z. Freud, Kultura jako źródło cierpień, [w:] Z. Freud, Człowiek, religia, kultura, tłum. J. Prokopiuk, Warszawa 1967, s. 240; por. też hasła: Zasada przyjemności i Zasada rzeczywistości i in., [w:] J. Laplanche, J.-B. Pontalis, Stownik psychoanalizy, tłum. E. Modzelewska, E. Wojciechowska, Warszawa 1996, s. 380-385 lub S. Fhaner, Słownik psychoanalizy, tłum. J. Kubitski, Gdańsk 1996, s. 281-286. 
śmierci, o nas samych jako wolnych podmiotach i istotach uwikłanych w jakiś los). Pisanie i czytanie traktować zawsze można jako terapię i autoterapię, której nie da się sprowadzić do tchórzliwej ucieczki od rzeczywistości. Obcowanie $\mathrm{z}$ tekstami to wyrywanie się z obszaru vita activa, przechodzenie do vita contemplativa po to, aby coś istotnego zrozumiećto rozważanie, myślenie, kontemplowanie, medytowanie, filozofowanie. O wartości i sile filozofowania przekonywał np. Arystoteles w swej Zachęcie do filozofii oraz Boecjusz w dziele O pocieszeniu jakie daje filozofia ${ }^{9}$. Obcowanie $\mathrm{z}$ tekstami staje się $\mathrm{w}$ tej perspektywie tożsame $\mathrm{z}$ rozmyślaniem - jest to poważna zabawa ludzi wolnych i rozumnych.

Mamy zatem dwa skrajnie różne i równie przekonujące podejścia do przyjemności, jaką stanowi czytanie i pisanie. Poruszać się będziemy między nimi, w dialektyce sensu i bezsensu, owocności i jałowości, radosnej ekscytacji i przygnębiającego znudzenia. Być może ambiwalencja ta okaże się nieusuwalna.

\section{Mit o narodzinach pisma}

Przywołajmy teraz Platoński mit o narodzinach pisma, wyraźnie ukazujący jego niejednoznaczny charakter. Platon przeciwstawia sobie prawdę idei i złudę fantazmatów. Uważa, że pismo jest dalej od prawdy niż mowa, zatem jest fatalną drogą poznania, wiodącą najczęściej na manowce. Rzeczywistość, prawda i szczęście znajdują się po jednej stronie, pozór chaos, mozół, trud, cierpienie, czcza gadanina i wielość opinii - po drugiej. Pismo na równi z malarstwem lokuje się po stronie fantazmatów. W Fajdrosie czytamy, że bóstwo niosące Egipcjanom dar pisma zapewniało, iż będzie ono środkiem prowadzącym do mądrości i pamięci. Tymczasem pismo sprowadziło na ludzi zapomnienie i pozór mądrości. Ludzie stali się zbieraczami licznych wiadomości, przemądrzałymi nieukami „trudnymi w obcowaniu” ${ }^{0}$. Sokrates powiada: „pismo ma coś osobliwego

9 Por. Arystoteles, Zachęta do filozofii, tłum. K. Leśniak, Warszawa 1988; Boecjusz, O pocieszeniu jakie daje filozofia, tłum. W. Olszewski, Warszawa 1962.

10 Platon, Fajdros, tłum. L. Regner, Warszawa 1993, 274E, 275AB. 
i doprawdy podobnego do malarstwa. Albowiem jego płody przedstawiają się jak żywe, jeżeli jednak zapytać je o coś, one bardzo dostojnie milczą. Podobnie też i mowy. Myślałbyś, że one niby mówią coś mądrego, jeślibyś jednak - chcąc się nauczyć - zapytał o coś z tego, co zostało powiedziane, one zawsze wyrażają jedno i to samo. Gdy się zaś raz napisało, cała mowa zwraca się wszędzie, zarówno do tych, którzy są z tym obeznani, jak - tak samo - do tych, którym nic nie pomoże, i ona nie wie, do kogo warto przemawiać, do kogo zaś nie. Pojmowana błędnie i narażona na niesłuszne zarzuty potrzebuje ciągle opieki tego, kto ją napisał. On sam jednak nie może ani być na podorędziu, ani wspomagać jej”"1.

Słowa spisane nie mogą zatem nikogo nauczyć prawdy, nie są też tworzone w tym celu. Teksty pisane powstają najczęściej z powodu próżności i niskiej ambicji ${ }^{12}$. A jednak Sokrates przyznaje, że niekiedy człowiek uczony i świadomy wad pisma „sadzi dla przyjemności ogrody z abecadła” i każdy, „kto pójdzie tym samym śladem, a oglądając te wytworne plony dozna rozkoszy"13.

\section{Lacan i nasze teksty}

W kontekście naszych rozważań bardzo ciekawie wypadają poglądy Jacques'a Lacana - jednego z najbardziej interesujących kontynuatorów Freuda - na związek języka z podmiotowością i nieświadomością ${ }^{14}$. Lacan rozróżnia to, co daje się wypowiedzieć (treść, sens, to, co jawne, oficjalne), od tego, co nie jest możliwe do wyrażenia w słowach (ach, te dychotomie!). Uważa też, że nasze Ja tkwi w miejscu, gdzie nie mówimy (gdzie tracimy głowę i brak nam słów), mówimy zaś wówczas, gdy nas nie ma, z miejsca, w którym nie jesteśmy obecni (dyskurs Innego). Podmiot językowy jest ontologicznie ufundowany w różnicy i jako taki pozostaje niespełniony,

\footnotetext{
11 Platon, Fajdros, dz. cyt., 275DE.

12 Platon, List siódmy, [w:] Platon, Listy, tłum. M. Maykowska, Warszawa 1987, 342BCD, 343,344 .

13 Platon, Fajdros, dz. cyt., 276D.

14 Por. M. Obrębska, Szkic do koncepcji podmiotu według J. Lacana, [w:] Tożsamość indywidualna i zbiorowa. Szkice filozoficzne, red. M. Żardecka-Nowak, W. Nowak, Rzeszów 2004, s. 125-134.
} 
niemożliwy, rozbity i wybrakowany. Najgłębsza jego istota pozostaje niewyrażalna i nieobecna nawet dla niego samego. To, co wypowiada, jest zawsze w jakimś sensie fałszywe; najbardziej prawdziwie wyraża się zaś w błędach i przejęzyczeniach ${ }^{15}$.

Poza językiem znajduje się w zasadzie wszystko, co najważniejsze w tym rozkosz, radość, szczęście. W słowach niewiele daje się ująć - teksty dotyczące żartów nie są zabawne, teksty dotyczące rozkoszy nie budzą jej itd. Rozkosz jest zakazana i niedostępna mowie. Ci, którzy mówią lub piszą, przez fakt, że posługują się językiem, odmawiają sobie rozkoszy (lub pozbawiają się jej). Natomiast ten, kto rozkoszy doznaje, wypiera się mowy, skazuje ją na rozpłynięcie się. Kto chce pisać i mieć dużo do powiedzenia, musi się liczyć z faktem odcięcia się od źródła radości i rozkoszy. Tylko rezygnując z nich, zyskuje się prawo zamieszkiwania w świecie języka. Mówiąc zaś, odbiera się sobie prawo i możliwość rozkoszy (ale też prawdopodobnie neutralizuje się doświadczenie bólu) ${ }^{16}$.

Miłośnicy książek zamieszkują królestwo po wieży Babel, którego porządek oraz geneza są bardzo niejednoznaczne. Biblioteki to wszechświaty, które można bez końca przemierzać, ale także więzienia i labirynty, z których nie można się wydostać ${ }^{17}$. To kosmosy dla zapalonych astronautów, ale i chaosy dla zbłąkanych i obłąkanych - porządek alfabetyczny w katalogach nie jest żadnym porządkiem, jest imitacją porządku, listkiem figowym zakrywającym wielki nieład. Biblioteki to magazyny książek, które wszystko twierdzą, wszystko negują i wszystko mieszają. Życie pośród książek, strawione na pisaniu i czytaniu, jest naznaczone nieuchronną ambiwalencją - nie wiadomo, czy bardziej jest ucieczką od rzeczywistości i od siebie, czy też bardziej próbą godzenia się ze sobą

15 Por. M. Obrębska, W poszukiwaniu ukrytej struktury, Poznań 2002, s. 86; por. też: J. Lacan, Mit indywidualny neurotyka albo Poezja i prawda w nerwicy, tłum. T. Gajda i in., Warszawa 2015; S. Żiżek, Lacan. Przewodnik krytyki politycznej, tłum. J. Kutyła, Warszawa 2008; P. Dybel, Urwane ścieżki. Przybyszewski - Freud - Lacan, Kraków 2000, s. 209-280.

16 Ale poza mową znajdują się również i ci, którzy toną w oceanie bólu. Jean-François Lyotard w przejmujący sposób pisał o wykluczeniu cierpiących z grona mówiących. Por. J.-F. Lyotard, Poróżnienie, tłum. B Banasiak, Kraków 2010, s. 2, 7, 13n.

17 Metaforę biblioteki jako wszechświata rozwija Jorge Luis Borges w opowiadaniu Biblioteka Babel, [w:] J. L. Borges, Opowiadania, tłum. Z. Chądzyńska, Kraków 1978. 
i światem. Podobnie niejednoznaczne sąźródła pasji pisarskiej. Pisarstwo uważa się z jednej strony za przejaw kreatywności, której inspiracją jest zdrowie, radość i poczucie pełni życia (John Dewey), z drugiej zaś za stan chorobowy i poszukiwanie wyrazu dla traumy, frustracji, wewnętrznego konfliktu (Zygmunt Freud).

Niektóre odmiany pisarstwa wymierzone są przeciw szaleństwu i neurozie, inne - przeciw tyranii, wojnie i przemocy. W niektórych przypadkach uderza nas jedność dzieła i życia ${ }^{18}$, w innych - całkowita ich odmienność, odrębność, nawet sprzeczność ${ }^{19}$. Niektóre dzieła zdają się przydatne w budowaniu indywidualnej tożsamość (autora lub czytelnika), inne - w umacnianiu tożsamości narodowej lub religijnej. Mamy do dyspozycji wiele różnych form literackich: opowiadanie, pamiętnik, esej, dziennik, nowela, powieść, saga, traktat filozoficzny, autobiografia, biografia, zbiór sentencji itd., a wybór ten nie jest błahy dla przedstawianej treści. Nie ulega wątpliwości, że lektury wpływają na to, kim jesteśmy i jak postrzegamy świat ${ }^{20}$.

Miłośnicy książek odwrócili sens biblijnej przypowieści o wierzy Babel - delektują się wielością i rozmaitością tekstów, języków, opowieści, teorii, narracji, dyskursów. Cóż oni robią z tekstem? Przebiegają go, przeskakują, zapadają się weń, zatracają się w nim, zatapiają się. Tekst też nie zachowuje się wobec nich biernie, lecz wciąga ich i porywa (lub nudzi i odpycha). Książki można połykać, pożerać, skubać, przeżuwać, trawić itd. Aspołeczna jest natura tej przyjemności: czytam - chcę być sama! A jednak, gdy czytam i przez fakt, że czytam, znajduję się w świecie wspólnym i zaludnionym.

i Paul Ricoeur.

18 Wydaje się, że dobrym przykładem takiej jedności są autorzy tacy jak Karl Jaspers

19 Interesującym studium związków dzieła z życiem autora jest praca Clifforda Geertza Dzieło i życie (tłum. E Dżurak, S. Sikora, Warszawa 2000), w którym ukazana została specyfika twórczości antropologów kulturowych takich jak np. Claude Lévi-Strauss, Bronisław Malinowski, Edward Evans-Pritchard, Ruth Benedict i in.

20 Autorem przywiązującym olbrzymią wagę do swych wczesnych lektur był Marcel Proust (przywołuje je w wielu miejscach swego dzieła $W$ poszukiwaniu straconego czasu), ale warto też zajrzeć do pracy Alberto Manguela Moja historia czytania (tłum. H. Jankowska, Warszawa 2003) lub Henry’ego Millera Książki mojego życia (tłum. M. Fedyszak, Warszawa 2002). 
Produkowanie i odtwarzanie tekstów ma wiele znamion zachowań neurotycznych (przymus powtarzania, natręctwo). Czytam, a zatem poszukuję rozkoszy i przyjemności w ramach języka, nie poza nim, nie mogę oderwać się od tego tekstu, wielokrotnie powracam do tej książki, to dzieło mnie pochłania. Oddawanie się lekturze to nałóg i wyrafinowana przyjemność o charakterze wywrotowym i transgresyjnym. To nie jest przypadek, że tyrani zawsze lękali się czytelników i pisarzy. Czytelnicy i pisarze mają zaś inne lęki - boją się nie tylko rzeczywistości i prawdziwego życia, boją się przede wszystkim, że nie zdążą przeczytać wszystkiego, co przeczytać należy; boją się także każdego nowego dzieła, po które gorączkowo sięgają, gdyż może ono zburzyć pewną konstrukcję, którą utkali sobie z tekstów dotąd przeczytanych. Niepewność, ryzyko oraz otwartość na to, co nieznane, są częścią przygody z tekstem. Dobry tekst jest zawsze prawdziwym wyzwaniem.

\section{Solidarni z Don Kichotem}

Miłośnicy książek odnajdują samych siebie w postaci Don Kichota: „Otóż wiedzieć wam trzeba, że ów szlachcic, w chwilach kiedy nic nie miał do roboty (co zdarzało się przez większą część roku), wczytywał się $\mathrm{w}$ księgi rycerskie $\mathrm{z}$ takim zapałem i lubością, że o polowaniu zgoła zapominał oraz gospodarkę swej włości zaniedbywał; zaciekawienie to i zapamiętanie do tego stopnia doszły, że sprzedał liczne morgi ziemi ornej, byle zakupić do czytania księgi rycerskie, i znosił do domu wszystkie, jakie tylko mógł dostać; a ponad inne wynosił te, które ułożył Felicjano de Silva; bowiem blask jego prozy i zawiłe wywody zdawały się szlachcicowi istnymi perłami, szczególnie gdy rozczytując się w owych wyznaniach miłosnych lub wyzwaniach rycerskich, spotykał często takie słowa: «Przewaga nierozwagi, jaką sprawuje w mojej rozwadze, tak osłabia równowagę mej uwagi, że nie bez wagi żalić się muszę na waszej piękności przewagę...». Podobnie kiedy czytał: «...wysokie niebiosa, które w boskości waszej bosko was wraz z gwiazdami umacniają, czynią was zasługującą na zasługę, na którą zasługuje wielkość wasza...». 
Z tej przyczyny stracił biedny rycerz rozsądek i głowił się, by zrozumieć i rozwikłać sens, którego nie wydobyłby i nie pojął sam Arystoteles, choćby po to tylko zmartwychwstał. [...] Krótko mówiąc, tak się zapamiętał w swej lekturze, że na czytaniu trawił całe noce, od zmierzchu do świtania, i całe dni, od świtu do zmierzchu; dlatego też i z braku snu, a zbytku czytania, tak mu mózg wysechł, że wreszcie rozsądek stracił; nabił sobie wyobraźnię tym wszystkim, co w książkach wyczytał; były to same czary, zwady, bitwy, pojedynki, rany, zaloty, miłości, udręki i niemożliwe niedorzeczności. Tak sobie wbił do głowy, że cała ta wyczytana machina onych sennych majaczeń jest prawdą, iż nie było już dlań pewniejszych dziejów na świecie"21.

Nie mamy wątpliwości, kim jest Don Kichot, a jednak jesteśmy po jego stronie. Wzruszamy się na myśl o tym, że „cały jego byt to tylko język, tekst, zadrukowane stronice, historie już zapisane”, że „ma on tę samą naturę co tekst, z którego wyszedł"22. Rozumiemy, że spoczywają na nim niebagatelne obowiązki, o których trafnie mówi Michel Foucault: „Odwzorowując teksty, których jest świadkiem i męczennikiem, reprezentantem i analogonem, Don Kichote musi dać świadectwo i ukazać nie podlegające wątpieniu znaki, że teksty owe naprawdę są mową świata. Jemu przypadło wypełnienie obietnicy księgi” ${ }^{23}$. Ma on nadać realność pustym opowiadaniom i uczynić je prawdziwymi. Solidaryzujemy się z nim tym mocniej, im częściej słyszymy o kryzysie kultury i zmierzchu epoki książki. To niemożliwe - mówimy ${ }^{24}$.

\section{Radość czytania, radość pisania}

Czytanie jest radością. Szczególnie gdy napotykamy teksty skrzące się od erudycji, aluzji, metafor (oczarowanie). Dobry tekst jest jak muzyka, w której wielką wagę odgrywają rytm, ton, tonacja, intonacja, refren.

\footnotetext{
21 M. de Cervantes Saavedra, Przemyślny szlachcic Don Kichote z Manczy, tłum. A. L. Czerny, Z. Czerny, Warszawa 1955, s. 36-37.

22 M. Foucault, Słowa i rzeczy, tłum. T. Komendant, Gdańsk 2006, s. 53.

23 M. Foucault, Słowa i rzeczy, dz. cyt., s. 53.

24 Por. J.-C. Carrière, U. Eco, Nie myśl, że książki znikną, tłum. J. Kortas, Warszawa 2010.
} 
Oczywiście istnieją też teksty nudne, suche, drętwe, schematyczne, przygnębiające, fałszywe, które budzą rozczarowanie i które odrzucamy. Funkcją dobrego tekstu nie jest odzwierciedlanie rzeczywistości, lecz budowanie spektaklu posiadającego swą własną dramaturgię, logikę i formę. Dobry tekst jest spektaklem sensu. Nasze zaczytane ciało jest miejscem rozgrywania się dramatów i wyłaniania się sensów. Poszukiwanie sensu w słowach jest rozkoszą tych, którzy nie wierzą w inne rozkosze. Anihilacja rozkoszy w rzeczywistości zdaje się być warunkiem jej rozkwitu w tekstach. Ale cóż to za rozkosz? Zaledwie zasygnalizowana, miniona, utracona, spodziewana, niespełniona, niedostępna, upragniona, przeoczona itd. Słowa starają się zastępować nieobecne rzeczy. Kultura jest ojczyzną tych, którzy mówią, piszą, czytają, obsesyjnie, kompulsywnie dukają teksty, cytują, przytaczają, parafrazują bez końca. Wszyscy logofile, grafomani, bibliofile, bibliotekarze, literaci, lingwiści, filologowie, filozofowie w kółko czytają to, co już przeczytane, i piszą to, co już napisane, jakby byli skazani na obłędne plagiatowanie się nawzajem. Zawsze też mają przed sobą tysiące nieprzeczytanych książek. Miłośnicy tekstów to galernicy i komedianci, współautorzy i aktorzy komedii ludzkiej, następcy Syzyfa i Don Kichota.

Radość obcowania $\mathrm{z}$ tekstem nie występuje w postaci czystej, lecz zawsze jest zmącona. Czytam i nie rozumiem, nie pamiętam, błądzę, nie mogę się skupić, coś mnie rozprasza; czytam, lecz zaraz muszę przerwać itd. Czytanie jest wysiłkiem i pracą. Z kolei gdy piszę, zawsze mam poczucie, że nie trafiam we właściwe słowa, jakby pisanie było tożsame $\mathrm{z}$ chybianiem celu. Wszystko, co napisane, przychodzi na świat nieudane, nieaktualne, zbanalizowane, skompromitowane. Roland Barthes mówi, że: „wszystkie oficjalne instytucje językowe są maszynami do powielania: szkoła sport, reklama, mass-media, piosenka, informacja powtarzają w kółko tę samą strukturę, ten sam sens, nawet te same słowa; stereotyp stał się faktem politycznym, podstawową figurą ideologii”25. Posługiwanie się językiem to stereotypizacja - te same słowa, te same struktury gramatyczne. O języku jako nieubłaganej schematyzacji, przemocy 
i mechanizmie spychającym nas w anonimowość pisali liczni filozofowie (Martin Heidegger, Henri Bergson, Emmanuel Levinas). Tekst jest powtarzalnością. Powtarzać aż do upojenia to zatracać się, ale i za każdym razem znajdować się w tym samym miejscu. Pisanie i czytanie jest tylko dreptaniem w miejscu. We wszystkich tekstach przekazywana jest ta sama treść. Ciągle to samo. Kogo to bawi?

Foucault powiada, że całe to poszukiwanie sensu kieruje ostatecznie naszą uwagę w stronę obszaru, gdzie snuje się śmierć. To milcząca śmierć będąca czarnym słońcem języka funduje każdy nasz dyskurs oraz całe nasze życie ${ }^{26}$. Mówienie i pisanie jest sposobem zmagania się ze śmiercią za pomocą wiary pokładanej w słowie ${ }^{27}$. Pismo, dzięki swej funkcji symbolicznej, pozwala uzyskać pozór nieśmiertelności, przechować pamięć o przeszłości. Jednocześnie czas spędzony na pisaniu lub czytaniu jest czasem straconym dla życia. Przesiadywanie w bibliotekach, kolekcjonowanie książek, pisanie i czytanie to przyjemności sprowadzające się do wiecznego uciekania przed śmiercią - wyrzekamy się życia po to, by nie doświadczyć cierpienia i strachu przed śmiercią; uznajemy taki stan za jedyną dostępną przyjemność. $W$ ten sposób stajemy się hedonistami, a hedonizm to pesymizm, jak mówił Friedrich Nietzsche. Prawda, Wolność, Szczęście, Miłość i Świętość to cele wielkie i wzniosłe, które znajdują się zawsze poza mową i językiem. Szukanie spełnienia w pisarstwie to zakłamywanie swojej bezsilności i niemożności ich osiągnięcia. W końcu jednak musi okazać się, że Biblioteki przed niczym nie chronią. Cierpienie i tak się pojawia, a erudycja i elokwencja, tak jak frywolność i wesołkowatość, budzą jedynie pogardę i przygnębienie.

Świadomość rodząca się dzięki tekstom jest nieodmiennie świadomością nieszczęśliwą (Hegel) i świadomością fałszywą (Marks). „Za każdym razem, gdy próbuję zanalizować tekst, który sprawił mi przyjemność, odkrywam nie moją podmiotowość, lecz moją jednostkowość, datum, które sprawia, że moje ciało wyróżnia się pośród innych ciał i przypisuje sobie cierpienia i przyjemności: odnajduję własne ciało rozkoszy. A to

26 M. Foucault, Słowa i rzeczy, dz. cyt., s. 336.

27 Por. Z. Mikołejko, Śmierć i tekst, Gdańsk 2001, s. 7. 
ciało rozkoszy jest również moim historycznym podmiotem, ponieważ w wyniku pewnej bardzo subtelnej kombinatoryki elementów biograficznych, historycznych, socjologicznych i neurotycznych (edukacja, klasa społeczna, wychowanie w dzieciństwie itd.) prowadzę sprzeczną grę między przyjemnością (kulturalną) i rozkoszą (niekulturalną) i piszę jak podmiot źle uplasowany, przybyły zbyt wcześnie lub zbyt późno (to zbyt nie oznacza ani żalu, ani winy, ani pecha, lecz jest zaproszeniem donikąd) - jako podmiot anachroniczny, dryfujący" ${ }^{28}$. Podmiot czytający to podmiot rozwarstwiony, rozbity i niezdrowy. Rozkosz czytania jest trudna do uchwycenia i niemożliwa do zatrzymania; bardzo szybko przemienia się w grę drugorzędnych celów, takich jak próżność, samozadowolenie, prestiż, triumf, popis, parada, afisz.

Kto podróżuje, je, pije, tańczy, śpiewa, ten pełen jest radości życia. A ten, kto czyta? Czytelnik to osobnik podejrzany, bezproduktywny próżniak, bezużyteczny darmozjad. Kto zajmuje się tekstami, ten trwoni. Teksty to polifonia różnych głosów, syreni śpiew, który ekscytuje i wabi; to niekończące się odesłania do innych tekstów.

\section{Oczekiwanie na sens}

Ale pisanie i czytanie to nie musi być tylko zabawa pustymi znaczącymi. Nasłuchujemy różnych głosów w nadziei, że jednak ułożą się one w sens. Zdaniem Ricoeura życie ludzkie tym się cechuje, że nakierowuje się właśnie na sens. Tekst jest sposobem, w jaki jeden człowiek daje drugiemu znak swego istnienia. Chcieć zrozumieć to oddać sprawiedliwość tekstom i ich twórcom. Interpretowanie tekstów oznacza zawsze wysiłek rozumienia drugiego człowieka. Czytając i pisząc, ożywiamy znaczenia i przemieniamy nasze jednostkowe i przygodne życie w życie w rozległej przestrzeni kultury. Teksty wpływają na nasz sposób rozumienia siebie i świata; sprawiają, że nasze życie staje się życiem przemyślanym²9.

28 R. Barthes, Przyjemność tekstu, dz. cyt., s. 81.

29 P. Ricoeur, Czas i opowieść, t. 3: Czas opowiadany, tłum. U. Zbrzeźniak, Kraków 2008, s. 228. 
Ricoeur podtrzymuje w nas nadzieję, że przyjdzie taki moment, w którym osiągane przez nas rozumienie przestanie być odmianą wiem, a stanie się odmianą jestem ${ }^{30}$. W ten sposób dzięki tekstom i poprzez nie znajdziemy w końcu drogę do siebie i do świata oraz pojmiemy sens wiążącego nas etycznego zobowiązania do odpowiedzialności przed drugim człowiekiem i za drugiego człowieka. Owo etyczne zobowiązanie przekształca nas nie tylko w wiarygodnych autorów oraz w czytelników godnych zaufania, lecz również w ludzi, na których można polegać. W tej właśnie moralnej rewelacji cała przebiegłość tekstowego świata (chytrość rozumu?) znajduje swój finał. Przyjemność czytania i pisania nie jest zatem - taką możemy mieć nadzieję - przyjemnością pustą, lecz przedsmakiem sensu, który nie mieści się w słowach.

\section{Bibliografia}

Arystoteles, Zachęta do filozofii, tłum. K. Leśniak, Warszawa 1988.

Barthes R., Przyjemność tekstu, tłum. A. Lewańska, Warszawa 1997.

Boecjusz, O pocieszeniu jakie daje filozofia, tłum. W. Olszewski, Warszawa 1962.

Borges J. L., Biblioteka Babel, [w:] J. L. Borges, Opowiadania, tłum. Z. Chądzyńska, Kraków 1978.

Carrière J.-C., Eco U., Nie myśl, że książki znikna, tłum. J. Kortas, Warszawa 2010.

Cervantes Saavedra M. de, Przemyślny szlachcic Don Kichote z Manczy, tłum. A. L. Czer-

ny, Z. Czerny, Warszawa 1955.

Dybel P., Urwane ścieżki. Przybyszewski - Freud - Lacan, Kraków 2000.

Encyklopedia filozofii, red. T. Honderich, tłum. J. Łoziński, Poznań 1998.

Fhaner S., Stownik psychoanalizy, tłum. J. Kubitski, Gdańsk 1996.

Foucault M., Stowa i rzeczy, tłum. T. Komendant, Gdańsk 2006.

Freud Z., Kultura jako źródło cierpień, [w:] Z. Freud, Człowiek, religia, kultura, tłum. J. Prokopiuk, Warszawa 1967, s. 240-315.

Freud Z., Popędy i ich losy, tłum. K. Rak, [w:] Z. Rosińska, Freud, Warszawa 1993, s. 136148. 
Freud Z., Poza zasadą przyjemności, tłum. J. Prokopiuk, Warszawa 2005.

Freud Z., Przypominanie, powtarzanie, przepracowanie, tłum. A. Czownicka, [w:] K. Pospiszyl, Zygmunt Freud. Człowiek i dzieło, Wrocław-Warszawa-Kraków 1991, s. 266-272. Freud Z., Psychopatologia życia codziennego. Marzenia senne, tłum. L. Jekels, H. Ivanka, W. Szewczuk, Warszawa 1987.

Geertz C., Dzieło i życie, tłum. E Dżurak, S. Sikora, Warszawa 2000.

Lacan J., Mit indywidualny neurotyka albo Poezja i prawda w nerwicy, tłum. T. Gajda i in., Warszawa 2015.

Laplanche J., Pontalis J.-B., Słownik psychoanalizy, tłum. E. Modzelewska, E. Wojciechowska, Warszawa 1996.

Lyotard J.-F., Poróżnienie, tłum. B. Banasiak, Kraków 2010.

Manguel A., Moja historia czytania, tłum. H. Jankowska, Warszawa 2003.

Mikołejko Z., Śmierć i tekst, Gdańsk 2001.

Miller H., Książki mojego życia, tłum. M. Fedyszak, Warszawa 2002.

Obrębska M., W poszukiwaniu ukrytej struktury, Poznań 2002.

Obrębska M., Szkic do koncepcji podmiotu według J. Lacana, [w:] Tożsamość indywidualna i zbiorowa. Szkice filozoficzne, red. M. Żardecka-Nowak, W. Nowak, Rzeszów 2004, s. 125-134.

Platon, Fajdros, tłum. L. Regner, Warszawa 1993.

Platon, List siódmy, [w:] Platon, Listy, tłum. M. Maykowska, Warszawa 1987.

Pospiszyl K., Zygmunt Freud. Człowiek i dzieło, Wrocław-Warszawa-Kraków 1991.

Ricoeur P., Czas i opowieść, t. 3: Czas opowiadany, tłum. U. Zbrzeźniak, Kraków 2008.

Ricoeur P., Język, tekst, interpretacja, tłum. P. Graff, K. Rosner, Warszawa 1989.

Ricoeur P., O sobie samym jako innym, tłum. M. Kowalska, Warszawa 2003.

Żiżek S., Lacan. Przewodnik krytyki politycznej, tłum. J. Kutyła, Warszawa 2008. 